\title{
Water Footprint of Milk Produced and Processed in South Africa: Implications for Policy-Makers and Stakeholders along the Dairy Value Chain
}

\author{
Enoch Owusu-Sekyere *, Morné Erwin Scheepers and Henry Jordaan \\ Department of Agricultural Economics, University of the Free State, Posbus 339, Bloemfontein 9300, \\ South Africa; MorneErwinScheepers@gmail.com (M.E.S.); JordaanH@ufs.ac.za (H.J.) \\ * Correspondence: kofiwusu23@gmail.com; Tel: +27-514-019-743
}

Academic Editors: Arjen Y. Hoekstra, Ashok K. Chapagain and Pieter R. van Oel Received: 4 June 2016; Accepted: 27 July 2016; Published: 29 July 2016

\begin{abstract}
The current water scarcity situation in South Africa is a threat to sustainable development. The present paper has assessed the water footprint of milk produced and processed in South Africa using the procedures outlined in the water footprint assessment manual. The results show that $1352 \mathrm{~m}^{3}$ of water is required to produce one tonne of milk with $4 \%$ fat and $3.3 \%$ protein in South Africa. The water used in producing feed for lactating cows alone accounts for $86.35 \%$ of the total water footprint of milk. The water footprint of feed ration for lactating cows is about $85 \%$ higher than that of non-lactating cows. Green water footprint accounts for more than $86 \%$ of the total water footprint of feed ration for lactating cows. Green and blue water footprints are the highest contributors to the total water footprint milk production in South Africa. Water used for feed production for both lactating and non-lactating cows accounts for about $99 \%$ of the total water footprint of milk production in South Africa. Particular attention should be given to feed crops with low water footprints and high contribution to dry matter to provide balanced ration with low water footprint. Water users, managers and livestock producers should pay attention to green and blue water consumption activities along the milk value chain and design strategies to minimize them. Corn, sorghum and lucerne production under irrigation in the greater Orange River basin is sustainable, whereas oats production for silage in the same catchment area is not sustainable. Our findings provide the rationale for dairy producers and water users in the dairy industry to get an understanding of the degree of sustainability of their input and output combinations, production choices, and policy interventions, in terms of water use.
\end{abstract}

Keywords: dairy value chain; South Africa; milk; water footprint; water scarcity; water sustainability

\section{Introduction}

The global water scarcity situation is a major issue of concern to sustainable development and requires detailed assessment of water footprints in all sectors of the economy [1]. Water footprint assessment in the food and agricultural sector has been recognized as an important sustainability indicator in recent years [2]. The water footprint concept takes into account the volume of fresh water used to produce a product and it is measured along the entire product value chain, right from production of inputs to the stage where the final product reaches the consumers [3]. The water footprint measured along the value chain of the product, according to Hoekstra et al. [3], is categorized into blue, green and grey. The blue water footprint refers to the surface and groundwater that is consumed (including water that has evaporated and the water that was incorporated into the product) along the value chain of a product. The green component of the water footprint refers to all the rainwater that does not become run-off, but is consumed by the crop [3]. The volume of freshwater required 
to reduce the pollutants to ambient levels is referred to as the grey water footprint. The concept of water footprint is also well grounded in the Life Cycle Assessment approach (LCA) [2] and the Water Footprint Assessment Manual described by Hoekstra et al. [3].

Water footprint assessment across the entire value chain of livestock products is gaining prominence because the livestock industry has crucial deficits in meeting the food needs of the increasing human population without exerting potential impacts on water resources [4]. For instance, assessments of the water footprint of beef cattle and sheep production systems in Australia and New Zealand have been done by Ridoutt et al. [2] and Zonderland-Thomassen et al. [5]. In China, the water availability footprint of milk and milk products from large-scale farms has been assessed by Huang et al. [6]. Analysis of potential water use, water stress, and eutrophication impacts from US dairy has been done by Matlock et al. [7]. The water footprints of milk in Germany, the Netherlands, India, and Argentina, among others, have been assessed [8-11]. In the African context, Bosire et al. [12] have recently assessed the trends and spatial variation in freshwater use for meat and milk in arid, semi-arid and humid production systems in Kenya using nation-wide data. The water footprint of livestock feed production is by far the greatest consumer of water along animal value chains, as it uses more than $95 \%$ of all the water used along the value chain $[13,14]$. Unfortunately, none of the studies in the growing body of literature on livestock and dairy products has focussed on the South African dairy industry. This has resulted in a literature gap regarding the water footprint of dairy products, particularly milk, in South Africa.

Although Mekonnen and Hoekstra [15] assessed the water footprint of dairy cattle in South Africa, their assessment was based on global averages. No South African case study was considered in the assessment and this raises doubt whether regional- or country-specific case study footprints will be the same as the global averages. Blue and green water footprints of lucerne for milk production in South Africa were recently assessed by Scheepers and Jordaan [16]. However, the focus of their study was on lucerne production for use as animal feed in the dairy industry and not on the dairy products. Hence, little information is available to guide and inform policy makers in policy formulation and integrated water resources management in the dairy sector at regional and national levels. Meanwhile, pressure is mounting on government and policy makers regarding allocation of water resources because fresh water is becoming increasingly scarce in South Africa [17].

South Africa is ranked as the 30th driest country in the world [17]. The agricultural sector, which includes the meat and dairy industry, uses up to $60 \%$ of the available water in South Africa [16]. Also, about $40 \%$ of the exploitable runoff is used for irrigating crops and pastures for feeding livestock [18]. This implies that the agricultural sector is a major user of freshwater in South Africa. However, given the relevance of agriculture and the essential role that water plays in agriculture, there is the need for water footprint and sustainability assessment in the agricultural sector. For instance, the livestock sector contributes about $40 \%$ to the gross value of agricultural production in South Africa [19]. The dairy industry alone contributes $14 \%$ to the gross value of animal production, and $7 \%$ of the gross value of agricultural production in South Africa [19]. This sector alone comprises of about 4000 milk producers. It further provides direct and indirect employment for about 100,000 people along the dairy value chain [19], emphasising the relevance of the industry to socio-economic development. Therefore, it is crucially essential to understand the degree of sustainability with which freshwater is used in dairy production. Such sustainability information will accurately and effectively inform water managers and water users towards the sustainable use of freshwater in dairy production, while sustaining the socio-economic benefits from the industry. Sustainability assessment in the dairy industry will reveal the water use behaviour from the view point of blue water availability in order to precisely understand whether the behaviour of water users in the industry is environmentally sustainable or not.

The present paper endeavours to fill the gap in the literature while contributing to the sustainability objective by assessing the water footprint of milk produced and processed in South Africa. Large water users along the milk production chain are identified for policy purposes. 


\section{Methodology}

\subsection{Conceptual Framework and Empirical Models}

The study adopted the concept of water footprint as described in the Water Footprint Assessment Manual by Hoekstra et al. [3]. The water footprint indicates freshwater use (direct and indirect) of a consumer or product. Hoekstra et al. [3] stressed that the water footprint can be regarded as a comprehensive indicator of freshwater use and should be used along with the traditional and restricted measures of water withdrawal. The water footprint concept, as described in the Water Footprint Assessment Manual, has been widely adopted to estimate the water footprint of an individual, a product, community, business or a nation [20-22]. This method is preferred because it is multidimensional, revealing water consumption volumes by source and polluted volumes by type of pollution [23]. Some authors have also applied the Life Cycle Assessment approach (LCA) to assess water footprints of animal products $[2,9,11]$. However, the LCA concept does not account for rainwater used by crops and the grey water footprint [3].

In this paper, the focus is on the water footprint of milk production from cattle. Conceptually, the water footprint of milk is defined as the total volume of freshwater used to produce the milk [3]. The water footprint concept adopted in this study gives a distinction between the green, blue and grey water used in producing milk. This implies that the concept offers an all-inclusive and comprehensive indication of freshwater consumption and pollution. The chain-summation approach for estimating water footprint of a product as described by Hoekstra et al. [3] was used, since our focus is on milk and not a variety of products [3]. The water footprint of milk consists of different process water footprints. These processes are made up of direct and indirect water footprints. The direct water footprint relates to the service water and the water that the live animals drink, while the indirect water footprint is the water used for feed production [3]. The formula specified by Chapagain and Hoekstra [24] for calculating the water footprint of live animals was employed to calculate the water footprint of the cows. The service water refers to the water used for washing the animals, cleaning the farmyard, and all other water used in order to maintain the production environment [3]. Animal water footprints are usually expressed in terms of $\mathrm{m}^{3}$ /year/ animal or $\mathrm{m}^{3}$ /animal, when summed over the entire lifespan of the animal. The estimation of the water footprint for feed followed the method outlined in the work of Mekonnen and Hoekstra [13,21].

As indicated by Mekonnen and Hoekstra [13,21], the feed ingredients for formulating feed ration in a country comes from both domestic production and imported products. Therefore, we took the weighted average water footprint according to the relative volumes of domestic production and imports in the calculation of the water footprint of animal feed [13]. The equation for estimating water footprint of feed ingredient is specified in Mekonnen and Hoekstra [13]. After estimating the water footprint of the feed, it is worth noting that the composition and the volume of the feed need to be determined, given that feed consumption varies depending on breed of animal, the production system and the country. Total dry matter intake, feed conversion efficiency and milk output per cow were recorded using electronic feed calculators. Feed conversion efficiency (FCE) was recorded as the ratio of total feed intake per cow over milk output per cow. The milk yield per dairy cow was multiplied by the total number of dairy cows to obtain the total milk yield.

It must be emphasized that the blue, green and grey water footprints of some feed crops used in South Africa are estimated separately. Hence, the water footprints at the processing phase of the value chain are added to get the total water footprint. We assumed that the volume of water used at retail level for cleaning is negligible in relation to the complete value chain, and it will therefore not be included in this study. The final blue water footprint is then an indicator of the total amount of surface and ground water that has evaporated together with the water that was incorporated into the final product. No green water is used in the processing and retailing of dairy products, so the green water used for the feed production, including the natural vegetation for pastoral grazing, is the total green water footprint of the milk value chain in our study. Grey water from the production of feed 
ration for the lactating cows was estimated as a leaching requirement to maintain the good productive potential of the soil. No blue water originated from the processing plant, as the fresh water that was used for cleaning the facility was recycled and later used for cleaning the cattle runs and the floor of the dairy parlour. The service water thus becomes grey water in the effluent pond and was accounted for according to the grey water methodology [3]. The grey water emanating from the faeces and urine of the lactating cows was estimated with the use of an effluent sample analysis, and the volume was measured as the flow into the effluent pond. From the analysis, the electrical conductivity (EC) of the effluent pond was taken and multiplied by the total volume of the effluent, and the salts originating from the abstracted water were then subtracted to obtain the total salts added to the effluent at the facility. The volume of water required to assimilate this load to below the acceptable level is then the grey water for milk processing. The formulas for estimating the blue, green and grey water footprints are clearly outlined in the Water Footprint Assessment Manual by Hoekstra et al. [3].

\subsection{Sustainability Assessment}

Sustainability assessment of water use in milk production from cattle was done after calculating the volumetric water footprint of milk. This was done to ascertain whether water use in the catchment area for milk production is sustainable or not. The blue water footprint used in the dairy industry is regarded as unsustainable if the blue water footprint exceeds blue water availability in the milk-producing catchment area. It must be emphasised that the blue water footprint and blue water availability were determined for the particular catchment area at definite time periods due to seasonal changes in water use and run-off. Hoekstra et al. [25] expressed blue water availability in a catchment for a particular time period as the difference between the natural run-off in the catchment and environmental flow requirement. Refer to Hoekstra et al. [3] and Scheepers and Jordaan [16] for the equation regarding blue water availability.

The environmental flow requirement for a particular catchment area at a certain time period is not met when the blue water footprint surpasses the blue water availability in the catchment. The environmental flow requirement denotes the volume and timing of water flows needed to ensure freshwater ecosystems and human livelihoods. Failure to meet the environmental flow requirement indicates unsustainable water use. Hoekstra et al. [25] further revealed that the blue water footprint sustainability assessment can be estimated by means of an index known as the blue water scarcity index. Refer to Hoekstra et al. [3] for the empirical specification of blue water scarcity index.

The blue water availability is unsustainable if blue water scarcity index is greater than 1 for a particular catchment area for a specific time period [3]. A catchment area where blue water scarcity index is greater than 1 at a point in time is regarded a hotspot [3]. Such catchment areas need intervention to ensure sustainability of freshwater use at the relevant time period.

\subsection{Data Description}

Data used in this paper consists of both primary and secondary data. The data covers the entire dairy value chain, with a focus on milk sold at processing level. Secondary data on water usage for the production of feed crops were obtained from Van Rensburg et al. [26]. Once the feed crops are produced, they become important inputs for dairy production and the link between the feed crops and dairy value chains is made. Therefore, data on water used in the commercial dairy farm and dairy processor is needed. This data was collected through questionnaires and interviews with the managers of the various divisions at the case study agribusiness. The business consists of both a commercial dairy and a processing plant where milk is processed and bottled. Data associated with irrigation was taken from the Vaalharts Irrigation Scheme. Important feed crops are produced under this scheme. Detailed information on measuring sites and systems can be obtained from Van Rensburg et al. [26]. The data were recorded over four seasons (two winters and two summers).

Data on water usage were measured on a weekly basis at every measuring point. These weekly measurements enumerated rainfall, irrigation, soil water content, water table depth, and drainage 
from artificial drainage systems, if any, as well as electrical conductivity (EC) of the irrigation water, water table and drainage water. The rainfall and irrigation were measured with rain gauges placed on the surface of the soil, with a $6 \mathrm{~m}^{2}$ cleared area around each rain gauge in order to prevent interference from the crop. Soil water content was measured with a calibrated neutron probe. The depth of the water table was measured manually by using an electronic device, while the volume of drainage water flowing from the artificial drainage systems was measured with a bucket and converted to $\mathrm{L} \cdot \mathrm{min}^{-1}$. Changes in irrigation, rainfall, soil water content, and drainage from artificial drainage systems were all measured, of which the latter mentioned also apply to the change in salt content of the soil, and salts added through rainfall and irrigation, as well as salts removed through the artificial drainage system. The net amount of salt applied through fertilisation (SF) was calculated as the difference between salt applied through fertilisers and salt removed by the crop.

Data on water used to produce milk were collected from the milk producers and Milk SA [27]. Farms considered in the study have feed calculating systems with electronic recordkeeping of the dry matter intake, feed conversion efficiency, and milk output per cow. The data recorded per animal was multiplied by the total number of animals to attain the aggregated data for the whole dairy farm. The data obtained were used in the calculations of the water footprint of feed ration. No further estimation was done to determine the dry matter intake (DMI) and feed conversion efficiency (FCE) for lactating cows since accurate data were available from the producers. The electronic feed calculator system also has information on quantities of the various inputs in the feed ration, their moisture content and nutritional values. The DMI guidelines of Stalker et al. [28] together with the average body weights set out by Bowling and Putnam [29] were used to determine the total feed consumption for the non-lactating cows. This method was used since the electronic feed calculator did not record information on non-lactating cows. We estimated DMI of all the non-lactating animals in order to get comprehensive information on water and feed intake. The total DMI was then multiplied by $385 \mathrm{~m}^{3}$ as reported by Mekonnen and Hoekstra [20] in order to calculate the water footprint for the non-lactating cows fed mainly on grazing lands or pastures. Also, the guidelines suggested by Ensminger et al. [30] were used to generate data on water intake by the non-lactating animals on the case study dairy farm. The estimation of water intake by lactating cows was based on the Little and Shaw [31].

\section{Results and Discussion}

\subsection{Water Usage in Feed Production for Dairy Cows}

Table 1 presents the water use for feed production for lactating cows. The results show that the total water footprint for producing feed for 825 lactating cows is about 9.08 million· $\mathrm{m}^{3}$ of water per year. The actual amount of green water used for feed production for the lactating cows is about 7.85 million. $\mathrm{m}^{3}$ per year, $782,161 \mathrm{~m}^{3}$ and $447,676 \mathrm{~m}^{3}$ of blue and grey water were used per year, respectively for all the lactating cows. This implies that $8.61 \%$ of the total water footprint is blue water, $86.46 \%$ is green water and $4.93 \%$ is grey water. Specifically, the actual amounts of blue, green and grey water used for feed production for a lactating cow are $948 \mathrm{~m}^{3}, 9521 \mathrm{~m}^{3}$ and $543 \mathrm{~m}^{3}$ per year, respectively. This implies that feed production for lactating cows is largely dependent on green water, followed by the blue water and grey water, respectively. Among the feed crops, high protein concentrates (including soybean cake, canola cake and sunflower cake) and maize meal had the highest green water footprints of 2.51 million $\cdot \mathrm{m}^{3}$ and $2.25 \mathrm{million} \cdot \mathrm{m}^{3}$ per year, respectively. Lucerne and maize silage has the highest blue water footprints of $217,942 \mathrm{~m}^{3}$ and $188,961 \mathrm{~m}^{3}$ per year, respectively. Additionally, maize meal and lucerne silage recorded the highest grey water footprints respectively. Since green water is the largest contributor to the total water footprint for feed production for lactating cows, particular attention should be given to feeds such as maize meal, high protein concentrate feeds, soybean and sunflower oil cakes which have high green water footprints in order to minimize green water consumption in the feed industry. Also, since blue water is directly associated with production cost, particular attention should be paid to feeds such as lucerne, maize, sorghum and 
oat silages to make sure that they are efficiently and sustainably produced. The results further show that the formulation of high protein concentrates and maize meals contribute the highest to the total water footprint for feeding lactating cows per year, among all the feeds.

Table 1. Water use in feed production for lactating cows per year.

\begin{tabular}{|c|c|c|c|c|c|c|c|c|c|}
\hline Product & Kg DM & $\%$ & $\begin{array}{l}\text { Herd } \\
\text { Total }\end{array}$ & Tonne & $\mathrm{m}^{3} /$ Tonne & $\begin{array}{c}\text { Blue } \\
\mathrm{m}^{3} / \text { year }\end{array}$ & $\begin{array}{c}\text { Green } \\
\mathrm{m}^{3} / \text { year }\end{array}$ & $\begin{array}{c}\text { Grey } \\
\mathrm{m}^{3} / \text { year }\end{array}$ & $\begin{array}{l}\text { Total WF } \\
\text { m }^{3} / \text { year }\end{array}$ \\
\hline Lucerne & 1533 & 17.3 & $1,264,725$ & 1265 & 459 & 217,942 & 263,165 & 99,682 & 580,789 \\
\hline Oats Silage & 402 & 4.6 & 331,650 & 332 & 412 & 103,587 & 23,397 & 9965 & 136,949 \\
\hline Maize Silage & 1424 & 16.1 & $1,174,800$ & 1175 & 338 & 188,961 & 179,215 & 28,872 & 397,048 \\
\hline Maize meal & 2738 & 31.0 & $2,258,850$ & 2259 & 1086 & 0 & $2,256,175$ & 195,969 & $2,452,144$ \\
\hline HPC & 1789 & 20.3 & $1,475,925$ & 1476 & 1785 & 74,643 & $2,512,770$ & 47,560 & $2,634,973$ \\
\hline Soy oilcake & - & - & - & - & - & 53,400 & $1,662,502$ & 8797 & $1,724,699$ \\
\hline
\end{tabular}

Note: Source: Authors' calculations, 2015; HPC: High Protein Concentrate.

The water used in feed production for non-lactating cows is explained in the following section.

Table 2 presents the yearly feed intake and water utilized in producing feed for non-lactating cows. The results indicate that the total water footprint of feed for all the non-lactating cows fed solely on grazing is about 1.36 million $\cdot \mathrm{m}^{3}$ per tonne per year, all of which contributes to the total water footprint. About 53.09\% of the total water footprint for feeding non-lactating cows goes into feeding dry cows, $42.68 \%$ is utilized in feed production for heifers and only $4.23 \%$ goes into feeding bulls. This implies that, among non-lactating cows, feed production for dry cows utilizes more water compared with heifers and bulls.

Table 2. Yearly feed intake by the non-lactating cows on the case study farm.

\begin{tabular}{|c|c|c|c|c|c|c|c|}
\hline \multirow{2}{*}{ Parameters } & \multirow{2}{*}{ Number of Animals } & \multirow{2}{*}{ Live Weight (Kg) } & \multicolumn{4}{|c|}{ DMI } & \multirow{2}{*}{$\begin{array}{c}\mathrm{m}^{3} / \text { year } \\
385 \mathrm{~m}^{3} / \text { tonne }\end{array}$} \\
\hline & & & $\%$ of BW & Kg & Total & Tonne & \\
\hline Dry cows & 399 & 544.31 & $2.37 \%$ & 12.90 & 5147.10 & 5.15 & 723,704 \\
\hline Heifers & 886 & - & - & - & - & - & - \\
\hline $0-6$ months & 220 & 62.14 & $1.50 \%$ & 0.93 & 204.60 & 0.20 & 28,105 \\
\hline $6-12$ months & 206 & 171.38 & $2.10 \%$ & 3.60 & 741.6 & 0.74 & 103,989 \\
\hline $12-18$ months & 238 & 259.68 & $2.15 \%$ & 5.58 & 1328.04 & 1.33 & 186,898 \\
\hline 18-24 months & 156 & 332.48 & $2.20 \%$ & 7.31 & 1140.36 & 1.14 & 160,199 \\
\hline $24+$ months & 66 & 479.38 & $2.30 \%$ & 11.03 & 727.98 & 0.73 & 102,583 \\
\hline Bulls & 23 & 589.67 & $3.00 \%$ & 17.69 & 406.87 & 0.41 & 57,615 \\
\hline Total & 1308 & 2439.04 & - & 59.04 & 9696.55 & 9.70 & $1,363,093$ \\
\hline
\end{tabular}

\subsection{Water Intake by Cattle Herd and Service Water at the Processing Plants}

The total water intake of the complete herd and the service water used at the processing plants of the dairy industries are presented in Table 3. The results show that the total water intake of the complete cattle herd is $46,688 \mathrm{~m}^{3}$ of water per year. Out of this amount of water, lactating cows drink $31,350 \mathrm{~m}^{3}$ per year, representing about $67.15 \%$ of the total water intake per year. About $18.29 \%$ and $0.89 \%$ of the total water intake by the complete herd is consumed by heifers and bulls respectively. The estimates imply that the water intake of lactating cows in the study area is about $104 \%$ higher than that of all the non-lactating cows, 391\% and $267 \%$ higher than that of dry cows and heifers, respectively, suggesting that lactating cows are major consumers of the total water supplied to the complete herd.

The largest amount of service water is utilized in cleaning the milking tanks $\left(10,950 \mathrm{~m}^{3} /\right.$ year), followed by the milking apparatus and other uses. Overall, the total service water used at the processing facilities is $26,134 \mathrm{~m}^{3}$ of water per year. All the freshwater used in cleaning the processing plant and parlour are reused to clean the excrement of the dairy cows off the floors of the dairy parlour, and as such was regarded as effluent (no evaporation is considered). 
Table 3. Total yearly water intake by the complete cattle herd and service water used on the case study farm.

\begin{tabular}{|c|c|c|c|c|c|}
\hline \multirow{2}{*}{ Parameters } & \multicolumn{3}{|c|}{ Water Intake } & \multicolumn{2}{|c|}{ Service Water } \\
\hline & Number of Animals & $\mathrm{m}^{3} /$ animal/year & Total $\left(\mathrm{m}^{3} /\right.$ year $)$ & Cleaning and Sanitation & $\mathrm{m}^{3} /$ year \\
\hline Total herd size & 2133 & - & - & Inline Pasturators & 2190 \\
\hline Dry cows & 399 & 16 & 6384 & Milk Tanks & 10,950 \\
\hline Heifers & 886 & - & - & Intake & 730 \\
\hline $0-6$ months & 220 & 5 & 1100 & Fillers & 2190 \\
\hline 6-12 months & 206 & 8 & 1648 & Floors & 2190 \\
\hline $24+$ months & 66 & 15 & 990 & - & - \\
\hline Bulls & 23 & 18 & 414 & - & - \\
\hline Total & 2133 & - & 46,688 & - & 26,134 \\
\hline \multicolumn{3}{|c|}{ Average yearly production per cow (tonne) } & 9.426 & \multicolumn{2}{|l|}{-} \\
\hline
\end{tabular}

Table 3 further shows that the average yearly milk production per cow per year is 9.426 tonnes. Given that the yearly dry matter intake of a lactating cow is 8.84 tonnes, the feed conversion efficiency is 1.07. This is too low according to findings from Hutjens [32], who opined that dairy feed conversion efficiency should range between 1.3 and 1.5. The low feed conversion efficiency may be attributed to errors in feeding management of the dairy cows or genetic factors, such as breed of cow as well as climatic factors such as heat stress.

\subsection{Water Footprint of Milk}

The water footprint of milk is presented in Table 4. The results reveal that $1352 \mathrm{~m}^{3}$ of water is needed to produce a tonne of milk with an average fat content of $4 \%$ and a protein content of $3.3 \%$. Specifically, the amount of water used for producing the tonne of milk with an average fat content of $4 \%$ and a protein content of $3.3 \%$ consists of $107 \mathrm{~m}^{3}$ of blue water, $1185 \mathrm{~m}^{3}$ of green water, and $60 \mathrm{~m}^{3}$ of grey water. The results indicate that green water forms the largest component of the total water footprint of milk production from cattle, as it accounts for about $87.65 \%$ of the total water footprint. Blue water on the other hand, accounts for about $7.91 \%$ of the total water footprint of milk. Comparing the water footprint of feed ration for lactating cows and non-lactating cows, we found that the water footprint of feed ration for lactating cows is about $85 \%$ higher than that of non-lactating cows (bulls, dry cows and heifers). Also, the water footprint of feed for lactating cows alone accounts for about $87 \%$ of the total water footprint for feed production. This implies that feed ration formulation for lactating cows under zero grazing is a major user of fresh water resources relative to non-lactating cows kept mainly on grazing. The results further reveal that about $88.23 \%$ of the total water footprint of feed ration for the complete herd is green water, $7.49 \%$ is blue water and $4.28 \%$ grey water. This suggests that green water footprint is the main contributor to the high water footprint observed for feed production, particularly for lactating cows.

Figure 1 presents the contributions of the various components to the total dairy water footprint. The results reveal that the water used in producing feed for lactating cows alone accounts for $86.35 \%$ of the total water footprint of milk and that of non-lactating cows accounts for $12.96 \%$. It is also shown that servicing water is only $0.25 \%$, while drinking water accounts for $0.44 \%$ of the total water footprint of milk. The above results suggest that about $99 \%$ of the water used in milk production from cattle goes into feed production. This provides further support for previous findings of Mekonnen and Hoekstra [13] and Hoekstra [14] who also reported that more than $95 \%$ of the water footprints of animal products related to water used for feed production. 
Table 4. Water footprint of milk.

\begin{tabular}{|c|c|c|c|c|c|}
\hline Parameters & Yield (tonne/year) & Blue $\left(\mathrm{m}^{3} /\right.$ year) & Green $\left(\mathrm{m}^{3} /\right.$ year) & Grey $\left(\mathrm{m}^{3} /\right.$ year $)$ & Total $\left(\mathrm{m}^{3} /\right.$ year $)$ \\
\hline Lactating cows & - & 31,350 & - & - & 31,350 \\
\hline \multicolumn{6}{|c|}{ Feed Production Water } \\
\hline Lactating cows & - & 782,161 & $7,855,021$ & 447,676 & $9,084,858$ \\
\hline Non-lactating animals & - & - & $1,363,093$ & - & $1,363,093$ \\
\hline Total yearly Pro & tion Water & $107 \mathrm{~m}^{3} /$ tonne & $1185 \mathrm{~m}^{3} /$ tonne & $58 \mathrm{~m}^{3} /$ tonne & $1350 \mathrm{~m}^{3} /$ tonne \\
\hline \multicolumn{6}{|c|}{ Service Water } \\
\hline Service & - & - & - & 26,134 & 26,134 \\
\hline Yearly Milk Processed & $13,196.58$ & - & - & - & - \\
\hline Total Yearly Se & ing Water & $0 \mathrm{~m}^{3} /$ tonne & $0 \mathrm{~m}^{3} /$ tonne & $2 \mathrm{~m}^{3} /$ tonne & $2 \mathrm{~m}^{3} /$ tonne \\
\hline
\end{tabular}

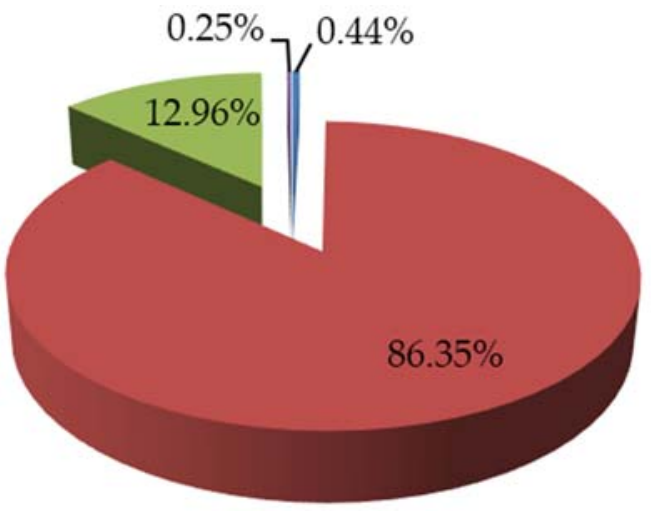

Drinking water

Water for Feed production

(Lactating cows)

Water for Feed production

(non-lactating cows)

Servicing water

Figure 1. Contribution of the various components to the total dairy water footprint. Source: authors' calculations, 2015.

\subsection{Sustainability Assessment}

Figure 2 shows the blue water scarcity of the Orange River basin, in which Vaalharts and the case study dairy farm are located. Figure 2 reveals that from January to May, and in December, there is a water scarcity index (WS) of below $100 \%$, since the blue water availability (WA) exceeds the blue water footprint (WF). During these months, there is low blue water scarcity with sufficient water available to satisfy the environmental flow requirements. However, in June and November, there is moderate blue water scarcity $(100 \%-150 \%)$. This causes slight modification of the runoff and hence the environmental flow requirements are not met. In July there exists significant blue water scarcity $(150 \%-200 \%)$ for which the runoff is significantly modified and does not meet the environmental flow requirements. August, September and October have water scarcity indices exceeding $300 \%$. The blue water footprints exceed $40 \%$ of the natural runoff during these months; runoff is thus seriously modified and environmental flow requirements are not met. Therefore, it is clear that the Orange River basin experiences low blue water scarcity during January, February, March, April, May and December. Of the feed crops used by the dairy farms for feeding cattle, maize is grown under irrigation between November and February, and sorghum is planted in December and harvested at the end of February. Hence, maize and sorghum production under irrigation in the greater Orange River basin is considered sustainable since the production does not distort the natural runoff significantly and environmental flow requirements are met. 


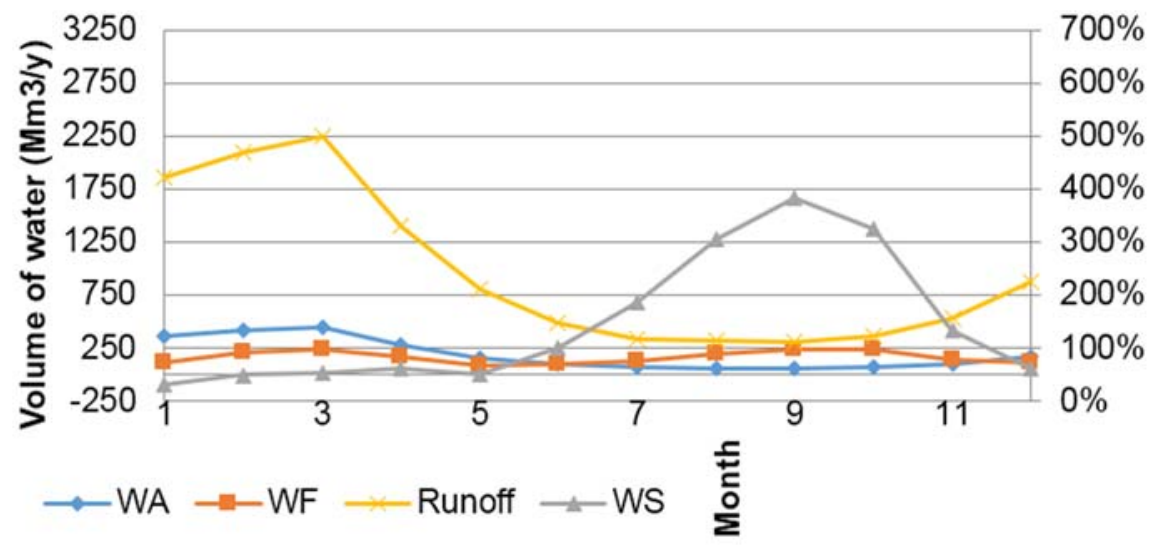

Figure 2. Monthly blue water scarcity of the Orange River basin. Source: Hoekstra and Mekonnen [33].

Lucerne production for feed has larger freshwater requirement since it falls in the summer months (December to February) when evapotranspiration is high. Therefore, lucerne production for livestock feed at Vaalharts is considered sustainable. Moderate blue water scarcity occurs in June and November, with significant blue water scarcity in July. Meanwhile, in August, September and October, there is severe water scarcity. The production of oats for silage takes place between June and October, depending on the planting date. June has moderate blue water scarcity; significant blue water scarcity in occurs in July; while August, September and October experience severe water scarcity. Therefore, oats production under irrigation in the Orange River basin is not sustainable from an environmental water flow requirement perspective and should, therefore, be reconsidered. More importantly, it is observed that the water scarcity index is greater than $100 \%$ in six of the 12 months of a year, which gives an indication that the Orange River basin is a hot spot. The major cause for concern to water users and managers is the fact that a large water scarcity index occurs in 4 of the 12 months in a year.

\section{Conclusions}

Given the emergence of water footprint assessment in various sectors of agriculture, the present paper has assessed the water footprint of milk produced and processed in South Africa using country-specific case studies. The study employed the concept of the water footprint described in the Water Footprint Assessment Manual. Based on the findings, it concluded that $1352 \mathrm{~m}^{3}$ of water is required to produce one tonne of milk with an average fat content of $4 \%$ and a protein content of $3.3 \%$ in South Africa. Water footprint for feed production accounts for a significantly larger portion $(99 \%)$ of the total water footprint of milk production from cattle in South Africa. It is worth noting that the water footprint of feed production for lactating cows alone accounts for about $87 \%$ of the total water footprint for feed production. Despite the significant amount of water used in feed production, we found that the feed conversion efficiency for lactating cows is too low. The low feed conversion efficiency leads to a higher water footprint of feed rations [12]. We therefore suggest that careful management of rangelands and pastures to improve feed availability and quality as well as breeding programs that aim at enhancing growth rates and milk yield per cow can improve feed conversion efficiency. This will in turn increase the efficiency and productivity of water in dairy production.

It is also concluded that the greatest portion of the total water footprint of feed for non-lactating animals goes into feeding dry cows. Therefore, in order to gain economic and water use efficiency, cattle farmers should aim at increasing output from dry cows to enhance feed conversion efficiency. Generally, we conclude that lactating and dry cows are the major consumers of fresh water along the milk production chain.

We conclude that the water footprint of feed production for lactating cows is largely dependent on green and blue water. Specifically, green and blue water accounts for $88.23 \%$ and $7.49 \%$ of the total 
water footprint of feed ration for the complete herd, respectively. Since our study focused on blue water scarcity assessment, we suggest that dairy livestock producers should pay particular attention to activities that lead to higher blue water footprint in feed ration formulation. For instance, particular attention should be given to feeds such as lucerne, maize, sorghum and oat silages should be carefully to make sure that they are efficiently and sustainably produced since they have high blue water footprints. Also, since blue water scarcity is a major issue of concern and, given the fact that blue water is directly associated with production cost, we suggest that dairy livestock producers should carefully evaluate the water footprint of the various feed crops and minimize or substitute the ones with high water footprints with lesser ones in order to be sustainable in terms of water use. However, the contribution of the various feed stuffs to dry matter and yield should not be overlooked. For instance, corn silage which is higher contributor to the blue water footprint can be replaced with triticale silage as it has been found to have low water footprints and high contribution to milk yield [34].

Although our findings reveal that lucerne, maize and sorghum have high blue water footprints, we conclude that their production under irrigation in the greater Orange River basin is sustainable. However, oats production for silage in the same catchment area is not sustainable. Hence, it is concluded that high water footprint of a product does not always mean that its production is unsustainable. This provides the rationale for livestock producers, policy makers and water users to get an understanding of the degree of sustainability of their input and output combinations, production choices, and policies interventions, in terms of water use. The large water scarcity index which occurs in 4 of the 12 months in a year in this particular catchment area should be of great concern to water users and policy makers in the area.

Acknowledgments: The paper is based on research that was conducted as part of a research project, "determining the water footprints of selected field and forage crops towards sustainable use of fresh water (K5/2397//4)", which was initiated, managed, and funded by the Water Research Commission (WRC). Financial and other assistance by the WRC are gratefully acknowledged. Financial assistance by the University of the Free State through the Interdisciplinary Research Grant is also gratefully acknowledged.

Author Contributions: Enoch Owusu-Sekyere wrote the paper and restructured it in the journal format after presenting it at conferences. Enoch Owusu-Sekyere did further analysis for publication. Morné Erwin Scheepers and Henry Jordaan conceived and designed the field survey and experiments. Morné Erwin Scheepers performed the preliminary analysis from the field data; Henry Jordaan supervised the two authors in the analysis, conceptualized the research idea, and assisted in the writing-up of the article.

Conflicts of Interest: The author declare no conflict of interest.

\section{References}

1. International Water Management Institute (IWMI). Water for Food, Water for Life: A Comprehensive Assessment of Water Management in Agriculture; International Water Management Institute Earthscan: London, UK, 2007.

2. Ridoutt, B.G.; Page, G.; Opie, K.; Huang, J.; Bellotti, W. Carbon, water and land use footprints of beef cattle production systems in southern Australia. J. Clean. Prod. 2014, 73, 24-30. [CrossRef]

3. Hoekstra, A.Y.; Chapagain, A.K.; Aldaya, M.M.; Mekonnen, M.M. The Water Footprint Assessment Manual: Setting the Global Standard; Earthscan: London, UK, 2011.

4. Zonderland-Thomassen, M.A.; Lieffering, M.; Ledgar, S.F. Water footprint of beef cattle and sheep produced in New Zealand: Water scarcity and eutrophication impacts. J. Clean. Prod. 2014, 73, 253-262. [CrossRef]

5. Godfray, H.C.J.; Beddington, J.R.; Crute, I.R.; Haddad, L.; Lawrence, D.; Muir, J.F.; Pretty, J.; Robinson, S.; Thomas, S.M.; Toulmin, C. Food security: The challenge of feeding 9 billion people. Science 2010, 327, 812-818. [CrossRef] [PubMed]

6. Huang, J.; Xu, C.; Ridoutt, B.; Liu, J.; Zhang, H.; Chen, F.; Li, Y. Water availability footprint of milk and milk products from large scale dairy production systems in Northeast China. J. Clean. Prod. 2014, 79, 91-94. [CrossRef]

7. Matlock, M.; Thoma, G.; Cummings, E.; Cothren, J.; Leh, M.; Wilson, J. Geospatial analysis of potential water use, water stress, and eutrophication impacts from US dairy production. Int. Dairy J. 2012, 31, 78-90. [CrossRef] 
8. Amarasinghe, U.; Smakhtin, V.; Sharma, B.; Eriyagama, N. Water Footprints of Milk Production: A case study in the Moga District of Punjab, India. 2010. Available online: https://cgspace.cgiar.org/handle/10568/39991 (accessed on 28 July 2016).

9. Drastig, K.; Prochnow, A.; Kraatz, S.; Klauss, H.; Plochl, M. Water footprint analysis for the assessment of milk production in Brandenburg-Germany. Adv. GeoSci. 2010, 27, 65-70. [CrossRef]

10. DeBoer, I.; Hoving, I.; Vellinga, T.; VandeVen, G.; Leffelaar, P.; Gerber, P. Assessing environmental impacts associated with freshwater consumption along the life cycle of animal products: The case of Dutch milk production in Noord-Brabant. Int. J. Life Cycle Assess. 2013, 18, 193-203. [CrossRef]

11. Manazza, J.F.; Iglesias, D.H. Water footprint in milk agrifood chain in the sub-humid and semi-arid central region of Argentina. In Proceedings of the International Association of Agricultural Economists (IAAE) Triennial Conference, Foz do Iguaçu, Brazil, 18-24 August 2012.

12. Bosire, C.K.; Ogutu, J.O.; Said, M.Y.; Krol, M.S.; de Leeuw, J.; Hoekstra, A.Y. Trends and spatial variation in water and land footprints of meat and milk production systems in Kenya. Agric. Ecosyst. Environ. 2015, 205, 36-47. [CrossRef]

13. Mekonnen, M.M.; Hoekstra, A.Y. A global assessment of the water footprint of farm animal products. Ecosystems 2012, 15, 401-415. [CrossRef]

14. Hoekstra, A.Y. The hidden water resource use behind meat and dairy. J. Abbr. 2012, 2, 2008-2013. [CrossRef]

15. Mekonnen, M.M.; Hoekstra, A.Y. The Green, Blue and Grey Water Footprint of Farm Animals and Animal Products Volume 2: Appendices; Value of Water Research Report Series No. 48; UNESCO-IHE: Delft, The Netherlands, 2010; Available online: http://www.waterfootprint.org/Reports/Report-48WaterFootprint-AnimalProducts-Vol2.pdf (accessed on 19 February 2016).

16. Scheepers, M.E.; Jordaan, H. Assessing the blue and green water footprint of lucerne for milk production in South Africa. Sustainability 2016, 8, 49. [CrossRef]

17. Department of Water Affairs. Strategic Overview of the Water Sector in South Africa, Pretoria: Department of Water Affairs. Available online: http://nepadwatercoe.org/wp-content/uploads/Strategic-Overview-ofthe-Water-Sector-in-South-Africa-2013.pdf (accessed on 4 January 2016).

18. Backeberg, G.R.; Reinders, F. Institutional Reform and Modernisation of Irrigation Systems in South Africa. Available online: http:/ / saili.co.za/sites/default/files/Backeberg\%20-\%20Institutional\%20reform\%20and\% 20modernisation.pdf (accessed on 4 January 2016).

19. Department of Agriculture Forestry and Fisheries (DAFF). Abstract of Agricultural Statistics; Department of Water Affairs: Pretoria, South Africa, 2014; Available online: http://www.nda.agric.za/docs/statsinfo/ Ab2012.pdf (accessed on 4 January 2016).

20. Chapagain, A.K.; Hoekstra, A.Y. Water Footprints of Nations; Value of Water Research Report Series No. 16; UNESCO-IHE: Delft, The Netherlands, 2004.

21. Mekonnen, M.M.; Hoekstra, A.Y. The Green, Blue and Grey Water Footprint of Farm Animals and Animal Products Volume 1: Main Report; Value of Water Research Report Series No. 50; UNESCO-IHE: Delft, The Netherlands, 2010; Available online: http:/ /www.waterfootprint.org/Reports/Report50-NationalWaterFootprints-Vol1. pdf (accessed on 19 February 2016).

22. Mekonnen, M.M.; Hoekstra, A.Y. The Green, Blue and Grey Water Footprint of Crops and Derived Crop Products Volume 1: Main Report; Value of Water Research Report Series No. 47; UNESCO-IHE: Delft, The Netherlands, 2010; Available online: http:/ / www.waterfootprint.org/Reports/Report47-WaterFootprintCrops-Vol1.pdf (accessed on 16 February 2015).

23. Berger, M.; Finkbeiner, M. Water footprinting: How to address water use in Life Cycle Assessment? Sustainability 2010, 2, 919-944. [CrossRef]

24. Chapagain, A.K.; Hoekstra, A.Y. Virtual Water Flows between Nations in Relation to Trade in Livestock and Livestock Products; Value of Water Research Report Series No. 13; UNESCO-IHE: Delft, The Netherlands, 2003; Available online: www.waterfootprint.org/Reports/Report13.pdf (accessed on 16 February 2015).

25. Hoekstra, A.Y.; Mekonnen, M.M.; Chapagain, A.K.; Mathews, R.E.; Richter, B.D. Global monthly water scarcity: Blue water footprints versus blue water availability. PLoS ONE 2012, 7, e32688. [CrossRef] [PubMed]

26. Van Rensburg, L.; Barnard, J.H.; Bennie, A.T.P.; Sparrow, J.B.; du Preez, C.C. Managing Salinity Associated with Irrigation at Orange-Riet at Vaalharts Irrigation Schemes; Water Research Commission (WRC): Pretoria, South Africa, 2012. 
27. Milk, S.A. The Milk SA Guide to Dairy Farming in South Africa, 2nd ed.; Agri Connect (Pty) Ltd.: Brooklyn Square, South Africa, 2014; Available online: http://www.milksa.co.za/sites/default/files / TheMilkSAguidetodairyfarminginSouthAfrica-2ndedition.pdf (accessed on 1 December 2014).

28. Stalker, L.; Meyer, T.; Volesky, J.; Adams, D.; Funston, R.; Klopfenstein, T.; Schacht, W. Technical Note: Estimating beef-cattle forage demand: Evaluating the animal unit concept. Prof. Anim. Sci. 2012, 28, 664-669.

29. Bowling, G.A.; Putnam, D.N. Growth studies with Ayrshire cattle. I. Normal body weights and heights at shoulders for Ayrshire cattle. J. Dairy Sci. 1943, 26, 47-52. [CrossRef]

30. Ensminger, M.; Heinemann, W.; Oldfield, J. Feeds \& Nutrition, 2nd ed.; The Ensminger Publishing Company: Clovis, CA, USA, 1990.

31. Little, W.; Shaw, S. A note on the individuality of the intake of drinking water by dairy cows. Anim. Prod. 1978, 26, 225-227. [CrossRef]

32. Hutjens, M.F. Practical approaches to feed efficiency and applications on the farm. In Proceedings of the Penn State Dairy Nutrition Workshop, Penn State University, College Station, TX, USA, 13-14 November 2007; Available online: http:/ / articles.extension.org/pages/26134/practical-approaches-to-feed-efficiencyand-applications-on-the-farm (accessed on 20 January 2016).

33. Hoekstra, A.Y.; Mekonnen, M.M. Global Monthly Water Scarcity: Blue Water Footprints Versus Blue Water Availability for the World's Major River Basins; UNESCO-IHE: Delft, The Netherlands, 2011.

34. Cosentino, C.; Adduci, F.; Musto, M.; Paolino, R.; Freschi, P.; Pecora, G.; D'Adamo, C.; Valentini, V. Low vs. high "water footprint assessment" diet in milk production: A comparison between triticale and corn silage based diets. Emir. J. Food Agric. 2015, 27, 312-317. [CrossRef]

(C) 2016 by the authors; licensee MDPI, Basel, Switzerland. This article is an open access article distributed under the terms and conditions of the Creative Commons Attribution (CC-BY) license (http:/ / creativecommons.org/licenses/by/4.0/). 